\title{
Developing an English Textbook for Early Childhood Education Program Students: A Need Analysis
}

\author{
Urip Sulistiyo $^{1 *}$, Khairunnisa ${ }^{2}$, Yolanda Demiza ${ }^{3}$, Nila Inayatillah ${ }^{4}$, Munawaroh $^{5}$, \\ Adrian Dinata Dwi Dharma ${ }^{6}$, Iccha Dhirdhena Prasadat Tungga Dewi ${ }^{7}$ \\ 1234567 Universitas Jambi, Jambi, Indonesia \\ *Corresponding Author: urip.sulistiyo@unja.ac.id
}

\begin{abstract}
This research aimed to develop English textbook for Early Childhood Education Program Students. The study utilized research and development $(\mathrm{R} \& \mathrm{D})$ with questionnaire and interview as the data collecting technique. Questionnaires were given to the students of early childhood education program that used to know the students' need. An interview was also delivered to the teacher to know the material for early childhood instructional material. The result found that data analysis of the early students' needs for learning English shows that learning four skills in English should have the same portion, namely between learning speaking, writing, reading, and listening. This study also found that the use of image media in learning is very necessary so that it helps students understand English learning material.
\end{abstract}

Keywords: English textbook, early childhood.

\section{BACKGROUND}

In daily life, English is really needed for every international sector. Even English can be found in all life aspects. In addition, in the current globalization era, proficiency in language, especially English, is one of the benchmarks for the quality of human resources, the ability to speak English can be used as a tool to expand relationships in the national and international world.

Considering the importance of English skills, introducing English to children as early as possible will be very useful, especially when they are not yet 12 years old [1]. In the age of 3-6 years is the age where children have the fastest ability to understand English, on the condition that they have to get used to pronouncing vocabulary or expressions in English.

Introducing English at this age will make them feel familiar to English. So that when they are faced English, it will not make them afraid to learn it. It will even feel more familiar every time they watch children's cartoons from overseas channels or even from YouTube.
In addition, children that have ability to speak English will have more value that it will make them easier to face the educational phases [1]. Because English skills were took into account since Elementary School. There are also many competitions and championship related to English and students whose being the champion will have more value in the eyes of the teacher. Therefore, it will support the children to develop.

When English becomes the language of instruction, the gates of their knowledge will be opened wider. As we already know, many learning resources both online and offline use English as the language of instruction. Armed with English language skills, children can explore the world of information from abroad and will make it easier for them to understand what is going on out there. They will understand the extent to which science has developed. Therefore, they will have broader knowledge and will support their grades in the classroom.

Learning English also helps children to be more mature when facing the future. Since, most of the 
professions cannot be separated by the use of English as well. Apart from being the communication language, English is also the language of knowledge and business. Mastering of English will be very beneficial when they intend to continue their studies abroad. Moreover, when they face the world of work, as mentioned above, almost all professions cannot be separated from the use of English. By providing English language skills at an early age, children will be better prepared to face their world later.

However, to make them ready for being educators for early childhood, early childhood education program students must equip themselves with various kinds of knowledge about children including how to teach them English appropriately. English is the most important foreign language in Indonesia, so it needs a process that begins with stages that are appropriate for the children's portion. Selection of teaching materials and methods must be in line with the development and be able to improve children's English language skills (Dian 2015)[2]. In addition, the learning atmosphere must also be fun and comfortable, considering that they have a fairly short level of concentration.

That matter explains how important the role of a teacher is in developing the English language skills of early childhood students. The teacher has a very crucial role in giving children the opportunity to use English both individually and in groups. The teacher's creativity will greatly affect the student's development [3]. Providing learning resources and paying attention to children's development in the use of English as a communication tool is a very important task. So, as a teacher, they must choose a variety of fun activities for children to maximize their active speaking well.

Before being a teacher, Early Childhood Education Program students must equip themselves with various kinds of knowledge about teaching early childhood children. As the institution responsible for the provisioning, Jambi University has also provided lectures in accordance with the curriculum for the study program. However, the textbooks available are still not applicable to be applied to local children. Since, the existing textbooks are the adoption of several publishers used. They are in accordance with the character of the children where the books are published. In connection with this issue, researchers has developed textbooks that suit the needs of local children so that both the material and teaching methods match their character.

The developed book is expected to help students in understanding the materials and methods of teaching English according to their level. So, they will also be able to maximize the English development of the children who are taught English. Based on the description above, researchers need to carry out development research as an alternative solution to solve problems through development research on an English Textbook for the Early Childhood Education Programs which first focused on the students' needs.

\section{THE IMPORTANCE OF RESEARCH}

As described, basically the benefits of developing this textbook are:

1. Filling in the shortage or the unavailability of textbooks according to the needs of the Jambi University early childhood education undergraduate students, with the hope of providing more understanding of the material and teaching methods in accordance with the related context.

2. Shaping students to be ready to face the world of work, where many factors must be considered when designing teaching materials for children.

3. Allowing for further research and development of book products for early childhood.

\section{LITERATURE REVIEW}

\subsection{Foreign Language Teaching for Early Childhood Education (PAUD)}

Teaching foreign language for early childhood students is very dependent on government policy in a country. Kaplan and Baldauf [4] defined language learning policy as a policy that refers to" who learns what language". 'Who' is the name for a group of learners who will learn a language, whoever they are adults, teenagers or children, and whether they are members of a particular group or community. 'What' refers to the language to be taught to a group of people, which can be the national language, the native language, or a foreign language. 'When' refers to the age or level at which the selected language is taught to a group of people. 
English has a status as lingua Franca, which is the language used globally for communication in international context. It is not surprising that English is taught from the highest level of education to the lowest level of education in a country. The use of English globally also encourages the addition of English subject to basic education curricula in Asian countries, where English is taught as a foreign language ([5][6][7]). According to Sulistiyo et al [8] the idea for adding English subjects to the elementary school curriculum does not only in linguistic considerations but also on economic, social, and political considerations. In Indonesia, parents are very enthusiastic about knowing their children are learning English at the basic level [6]. especially if they know their child is able to master vocabulary and pronounce basic sentences in English.

Regarding from that, the status of English as a local subject is currently known as a local subject. where government primary schools throughout Indonesia offers English as an elective subject or local content. In this case the school can determine, measure, and assess whether students should be taught English or not, according to the needs of students and the school's capacity to prepare teachers who can become instructors for teaching English. If so, then teachers who will teach English at the elementary school level can determine their own learning methods, materials and assessments.

\subsection{Method of Teaching English in Early Childhood Education and Teaching Materials}

One aspect of concern for teaching English at the primary school level is the teaching methods and materials provided. Teaching English at the primary school level focuses on communicative language skills. The methods used can be such as communicative language teaching (CLT) and task-based language teaching (TBLT).

The development of teaching materials or materials should also be considered. For example, in Korea, there are 16 English language textbooks that were first developed by the government for elementary school students in 1999 (the Korean Institute Curriculum and Evaluation, KICE). In addition, the development of textbooks was also carried out by the private sector and then legalized by the government. This is different from Indonesia. There has been no demand for the government to develop textbooks for teaching
English at the primary level because English in the education curriculum in Indonesia is local or optional. However, schools that makes English as the chosen subject to fill local content subjects really need a guide such as textbooks so that learning can run effectively. Teaching materials are designed to meet the needs of students to suit the characteristics of students and based on student activity plans. Harmer [9] stated that textbooks are guidelines or reference materials for teachers to deliver learning material, so that learning objectives can be achieved properly.

This English textbook for basic school level certainly must contain material and can be used for one semester. Aside from the topic or material, this textbook should contain instructions for activities or methods of implementing learning, as well as exercises and assignments needed to achieve an expected competency.

Definitely, the development of English textbooks for basic school levels must be customized based on needs of students. In Indonesia, there are many developments in English books that can be adapted for teaching English at the basic school level. However, the book is not necessarily adopted because the publication is commercial which is not authorized by the government accordingly curriculum recommendations. This means that the teacher can only think, sort and choose what textbooks or teaching materials are suitable for the students' needs. Obviouly, this adds to the burden on teachers, especially as English is not a subject in the Basic Education curriculum. To accommodate this, researchers see the need for textbooks for PAUD teachers that contain materials, exercises and forms of evaluation that are applied to teach English. Definitely, this book must accommodate and be able to answer questions about how to teach English methods for PAUD children, the form of exercises and activities carried out, as well as their assessments which of course must also be in accordance with relevant and developing theories nowadays.

\subsection{Analysis of the needs of Early Childhood in Learning English}

There is an assumption that the first six years of a child are a golden period, where at this time the child can easily master a certain task and easily accept external stimuli based on the stimuli given. Giving stimulation at this time will quickly be responded to by children as the 
results they can increase their potential. This period is also known as the golden age. In his book entitled 'The secret of childhood', Montessori [10] revealed that early childhood goes through a phase of life known as the sensitive period. Stimuli given from outside will get a quick response from the child, so that their development becomes fast. This development includes cognitive development, personality, social, physical, language and so on.

In Indonesia, one place that is expected to be the optimal place for early childhood growth and development is the Early Childhood Education institution. This institution is considered to have a very important and strategic role for the basic foundation for further education. The maturity of the child in the thinking process departs from the development that the child gets during education at this stage. Hakim and Dian [11] in their research revealed that social interaction or two-way communication experienced by early childhood with their peers, especially with adults, will be able to provide new ideas and improve the intellectual development of early childhood learners. In relation to teaching English, teachers can help students by bridging what students already know with what they need to know next (scaffolding). This assistance can be provided through assignments that are integrated with learning materials according to the conditions, needs and interests of students.

According to Brown [12], as seen from the praxis approach, there are five things that need to be considered in teaching the early childhood students. These five aspects include intellectual development, attention, sensory input, affective factors, and authentic (the meaningful language). Therefore, the connection of the teaching material or textbook development is important for the researchers or teachers to provide such kind of stimulus in the form of material based on their cognitive level and the use of authentic language that involves the surrounding environment as a source of teaching materials in teaching English itself (real context). The most important thing in teaching English to early childhood is the form of activity, to grown up the learning foreign languages, especially English. Then, it is necessary to know that the experience of teaching English is given to the students to provide a positive and pleasant perception of English. Then, they will be well-prepared for the higher level.

\section{METHODOLOGY}

This research aims to develop the English textbook for the early childhood students. This research involved teachers to emphasize the students need. It also involved the expert related to the field. The research was conducted at one of foundation school located in Jambi city.

The first process of collecting data was analyzing and exploring in more detail about the textbook that was used at the several schools in Jambi city. The analyzing process was focused on exploring the structure of the book, the competencies, the activities, and the assessment as well as the evaluation. As the result, the finding of this research formed the perception and opinion of analyzing the relevant document. In addition, the interview was held to the early childhood teacher to find out the students need.

\subsection{The Participant}

This research involved several early childhood teachers and the early childhood education program student at FKIP Jambi University. It was conducted to emphasize their needs of English teaching and learning process. Others, they were asked about the legibility of the book that was developed. The data were obtained from the result of investigating the need analysis, the questionnaires form and interview session. Moreover, the data were obtained from the document analysis that focused on exploring the textbook used from the others source such as internet.

\subsection{Need Analysis}

A needs analysis was carried out by researchers in May 2020. This needs analysis was conducted to see the needs of students for learning English in the S1 Early Childhood Education study program FKIP Jambi University. This need analysis looked at the extent of students' knowledge about English and what was not known yet and the things needed to be known at the stage of learning English at the next level in Higher Education. This need analysis was needed to ensure that the English learning material that will be given to students is right on target and relevant to the needs of students, especially for PAUD FKIP Jambi University students.

The needs analysis was formed based on the theory developed by Hutchinson and Waters in 1987. The 
instrument used was the questionnaire given to S1 PAUD students at Jambi University. This questionnaire was used to obtain data from students about their target needs and learning needs. The steps for taking data about students' needs analysis are as follows:

1. The questionnaires of the need analysis were distributed by using Google form virtually, due to the Covid-19 pandemic that happens in during the process of gathering the data. The students were asked for answer the questions related to their need in English learning process, by choosing a multiple answer given. They were also permitted to give the alternative answer by themselves if there were no the options at the questionnaires.

2. The interview session used as the secondary instruments to support the data. Some of early childhood teacher was hired to be contributed for this interview session. The interview data used for the information related to the real condition at the teaching and learning process. So that the researcher would get the whole real image about the material that was inputted to the textbook. The aims were to prepare all the needs and the competencies related to the students and the teachers as well.

Amount of the respondents that give the feedback of the questionnaires were 37 students. From the feedback, the results are follows:

\subsection{The Students' Need}

Learning needs are one of the elements in the needs analysis that are determined by the demands and needs of the certain situations. Inside the learning needs, the first factor that is seen is the purpose of learning English at the tertiary level of PAUD students. The table below shows the presentation of the objectives of learning English for PAUD students at Universitas Jambi.

Table. 1. The objectives of learning English

\begin{tabular}{|l|l|l|}
\hline Option & Objective & Presentage \\
\hline A & Being able to use English language by spoken and written context. & $40,54 \%$ \\
\hline B & Passing the English major examination. & $5,40 \%$ \\
\hline C & Supporting the future carrier. & $54,05 \%$ \\
\hline D & Supporting the learning process during in the University. & $0,00 \%$ \\
\hline E & Fulfilling their job-desk as the students. & $0,00 \%$ \\
\hline
\end{tabular}

The table above shows that more than 50 percent of students' goal of learning English is to support their future careers. More than forty percent of respondents stated that their goal in learning English is to be able to communicate in English both spoken and written. From these data it can be concluded that the majority of students want to learn English because of English is very important in supporting their careers and so that they are able to communicate in English both orally and in written. The next table is data about the students' future goals of learning English.

Table 2. The purpose of Learning English in the future

\begin{tabular}{|l|l|l|}
\hline The choice & The use of English Language in the future & Percentage \\
\hline A & Communicating with foreigners in global level & $40,54 \%$ \\
\hline B & Communicating by English language in the work field & $8,10 \%$ \\
\hline C & Understanding English terms used in Early Childhood Education context & $27,02 \%$ \\
\hline D & $\begin{array}{l}\text { Understanding English learning instruction for students in Early Childhood } \\
\text { Education }\end{array}$ & $16,21 \%$ \\
\hline E & Using English for work & $8,10 \%$ \\
\hline
\end{tabular}


The table shows that most of respondents want to learn English in order to be able communicating verbally with friends in the future. Hence, university students want to understand English learning instructions that might be useful for them later when they teach English subject in Early Childhood Education.
Besides, the data showed kinds of English skills that they will need to be learnt include Listening, Speaking, Reading and Writing. The data described as follows:

Table 3. Language Skills

\begin{tabular}{|l|l|l|}
\hline The Choice & English Skills & Percentages \\
\hline A & Listening & $27,02 \%$ \\
\hline B & Speaking & $27,02 \%$ \\
\hline C & Reading & $27,02 \%$ \\
\hline D & Writing & $18,91 \%$ \\
\hline
\end{tabular}

Regarding to the result showed in table, it is proven that when students were asked about "what they want to learn" most of them stated that they want to learn all of English skills include Listening, Speaking, Reading and Writing. From four of them, writing skill tends to has low percentage namely $18,91 \%$. Nevertheless, the difference of the percentages for each skill was not significant which means that writing skill is considered as important skill too. The following table presented the data related with language components that considered as important to be learnt by students.

Table 4. Language Components

\begin{tabular}{|l|l|l|}
\hline The choice & Language Components & Percentage \\
\hline A & Vocabulary & $54,05 \%$ \\
\hline B & Grammar & $10,81 \%$ \\
\hline C & Pronunciation & $35,13 \%$ \\
\hline D & Other components & $0,00 \%$ \\
\hline
\end{tabular}

The table shows that vocabulary got high percentage followed by pronunciation. It means that students considered vocabulary is crucial to improve their speaking skill since they will need a lot of vocabularies and good pronunciation for communication purpose. It is also in line with the previous data which revealed that their main purpose to learn English is to be able to speak and communicate using English for their career in the future. Following table presented the level of ability in mastering English.

Table 5. The Level of language ability

\begin{tabular}{|l|l|l|}
\hline The choice & Ability level & Percentage \\
\hline A & Beginner & $72,97 \%$ \\
\hline B & Early Intermediate & $24,32 \%$ \\
\hline C & Intermediate & $0,27 \%$ \\
\hline D & Advanced & $0,54 \%$ \\
\hline
\end{tabular}


From the data shows that majority of students felt not capable to put themselves at the beginner level. This is such a kind of crucial information for the researcher to arrange learning materials in the book. It is also useful for drafting syllabus as the part of activity to complete the learning materials that will be arranged.

In this research, the researcher also use interview as the instrument for collecting the data. There are three participants which is teacher in Early Childhood Education. The result of interview revealed that Early Childhood Education teachers have same needs. When a teacher is asked about the purpose of learning English in Early Childhood Education, they respond that the purpose of learning English in Early Childhood Education is to teach children about basic vocabulary such as colors, numbers, as well as the names of fruits and animals. The following are excerpts of the results of interviews with Early Childhood Education teachers.

When teaching English subject, we teach the students about vocabulary that related to the names of animals and fruits. We also teach them songs in English. (Teacher 1)

We teach children about colors in English. As teachers, we should know English children's songs because we teach vocabulary sometimes by using songs and it was more effective I think (Teacher 2)
The concept of learning in PAUD is "learning while playing" so as teachers we should combine English learning as well as playing. (Teacher 3)

The result of interview proven that Vocabulary is English material that teachers taught in Early Childhood Education. The learning method in Early Childhood Education is tend to be "learning and playing" therefore teachers need English skills to prepare themselves become English teacher not only in pedagogical context but also preparing the contents and professional competencies [13]. Regarding to the procedure for English book arrangements for Early Childhood Education students, the researcher get important information about the need of learning English songs so Early Childhood Education students have knowledge and experience in teaching English while playing with song as the media to deliver materials for children in Early Childhood Education.

\subsection{Learning Needs}

Concerning learning needs, researchers look at what kind of learning model or method is needed by students and how these needs can be accommodated and facilitated in an English textbook for students of the Early Childhood Education program that is compiled later. The data in the table below show whether students think the use of pictures in books helps them in learning.

\subsubsection{The use of Pictures in Textbooks}

Table 6. Use of Pictures in Textbooks

\begin{tabular}{|l|l|l|}
\hline Option & The use of picture & Percentage \\
\hline A & Very helpful & $78,37 \%$ \\
\hline B & Helpful & $21,62 \%$ \\
\hline C & Less Helpful & $0,00 \%$ \\
\hline D & Not helpful & $0,00 \%$ \\
\hline
\end{tabular}

From the table above, it can be seen that the use of Image media is very helpful for students in understanding English material. This information is very important later in that in preparing textbooks to be compiled later, researchers need to provide pictures, illustrations, and tables that will attract the attention of book users and help them understand the contents of the textbook [14].

\subsection{Learning Topics}

The following table shows data on what topics students need and want in learning English. 
Table 7. Preferred learning topics

\begin{tabular}{|l|l|l|}
\hline Option & Favorite topic & Percentage \\
\hline A & Daily life & $21,62 \%$ \\
\hline B & Life on Campus & $0,00 \%$ \\
\hline C & Material on Early Childhood & $78,73 \%$ \\
\hline D & Other material & $0,00 \%$ \\
\hline
\end{tabular}

From the table above, it can be seen that the topics that students like are topics related to Early Childhood Education and topics related to daily life. From the data above, it can be concluded that the learning material to be compiled in the textbook must refer to contextual learning [15] which originates in daily activities and contains material about early childhood.

\subsection{Learning materials}

\subsubsection{Listening Learning Materials}

The following table is data about the desired delivery model in listening learning.

Table 8. Listening Learning Model

\begin{tabular}{|l|l|l|}
\hline \multicolumn{1}{|c|}{ Option } & \multicolumn{1}{|c|}{ Selected model } & \multicolumn{1}{|c|}{ Percentage } \\
\hline A & Simple Monologue or dialogue & $27,01 \%$ \\
\hline B & Monologue or Dialogue with picture & $51,35 \%$ \\
\hline C & Monologue or Dialogue with list of words & $0,81 \%$ \\
\hline D & Monologue or dialogue with expression & $13,51 \%$ \\
\hline
\end{tabular}

From the table above, it can be seen that the students want a listening learning model using simple dialogues or monologues and also with dialogue and monologues that use images as well. If you look at the distribution of the percentage figures for this listening learning model, it can be seen that there is no domination of certain learning models over other learning models. This suggests that they do not really choose a learning model like what they do in learning listening.

\subsubsection{Speaking Learning Materials}

The data below explains what learning models the students need in learning speaking.

Table 9. Speaking Learning Model

\begin{tabular}{|l|l|l|}
\hline Option & Selected model & Percentage \\
\hline A & Simple Monologue or dialogue & $40,54 \%$ \\
\hline B & Monologue or Dialogue with picture & $43,24 \%$ \\
\hline C & Monologue or Dialogue with list of words & $13,51 \%$ \\
\hline D & Monologue or dialogue with expression & $0,27 \%$ \\
\hline
\end{tabular}

From the table above, it can be seen that students want to learn speaking using monologue and dialogue models as much as $40.54 \%$ and by using monologues and dialogue with pictures are the models most favored by students. From this data it can be concluded that the use of pictures in the speaking learning material is preferred by students so that in the textbook design that will be made, the researcher will include the image element as a medium for speaking learning. 


\subsubsection{Reading Learning Materials}

The next data is reading skills learning material (reading). Researchers distributed questionnaires to see what material students want in learning reading. From the table below, it can be seen that they like the type of text in accordance with their field of knowledge, namely about early childhood education.

Table 10. Reading Material

\begin{tabular}{|l|l|l|}
\hline Option & Reading Material & Percentage \\
\hline A & Text in the form of monologue or dialogue & $27,02 \%$ \\
\hline B & Texts with pictures & $0,81 \%$ \\
\hline C & Texts related to the Early Childhood Education & $59,45 \%$ \\
\hline D & Authentic texts of daily life & $0,54 \%$ \\
\hline
\end{tabular}

From the table above it can be concluded that the reading material to be presented in the textbook must be material that is in accordance with the student's field of science, namely about early childhood education.
Meanwhile, what students need in writing learning materials is presented as follows.

\subsubsection{Writing learning materials}

Table 11. Writing Learning Materials

\begin{tabular}{|l|l|l|}
\hline Option & Writing Material & Percentage \\
\hline A & Model texts that I will write & $32,43 \%$ \\
\hline B & Vocabulary related to ECE & $35,13 \%$ \\
\hline C & Texts with Picture & $32,43 \%$ \\
\hline D & $\begin{array}{l}\text { Explanation about sentence } \\
\text { structure }\end{array}$ & $0,00 \%$ \\
\hline
\end{tabular}

From the table above, it can be seen that the writing material needed by students is writing related to early childhood education vocabulary. Then students also want to learn to write in English using the help of pictorial text [16]. Furthermore, students also want to learn the types or genres of writing skills.

\section{CONCLUSION}

This study aims to develop textbooks in English for Early Childhood Education students, Faculty of Teacher Training and Education, Jambi University. In the first stage of this research, namely the needs analysis stage and the syllabus design, it was found that Early Childhood Education FKIP UNJA students were at the beginner level in their English language skills. Furthermore, from the needs analysis data, they want to learn English, emphasizing vocabulary recognition and simple conversation. This is in line with the English learning material for Early Childhood students, which focuses on learning and recognizing English vocabulary which aims to train early childhood memory skills and at the same time introduce the basic English for children. Data analysis of the needs of Early Childhood Education students for learning English also shows that they think that learning four skills in English should have the same portion, namely between learning speaking, writing, reading, and listening. This study also found that the use of image media in learning is very necessary so that it helps students understand English learning material.

\section{REFERENCES}

[1] Oktaviani, Ayu, and Asahi Fauzan. 2017. "Teachers Perceptions about the Importance of English for Young Learners.” Linguistic, English Education and Art (LEEA) Journal 1(1):1-15. 
[2] Dian, Yohana. 2015. "Developing English Learning Materials for Grade X." (1):29-41.

[3] Aladrović Slovaček, Katarina, Željka Sinković, and Nikolina Višnjić. 2017. “The Teacher 's Role in the Creative Teaching of Literacy / Uloga Učitelja $u$ Kreativnom Poučavanju Pismenosti." Croatian Journal of Education - Hrvatski Časopis Za Odgoj i Obrazovanje 19(0):27-36.

[4] Al-Jazirah Newspaper, 12398.Kaplan, R. B. \& R. B. Baldauf, Jr. 2005.Language-in-education policy and planning.In E. Hinkel (ed.) Handbook of research in second language teaching and learning, 1013-1034. Mahwah, NJ: Lawrence Erlbaum.

[5] Alawwad, K. June 01, 2002. Teaching English and Computer Literacy at the Elementary Stage.

[6] Lestariyana, R. P. D., and H. P. Widodo.2018. "Engaging Young Learners of English with Digital Stories: Learning to Mean."The Indonesian Journal of Applied Linguistics 8: 489-495.

[7] Widodo, H. P. 2016. Engaging Young Learners of English in a Genre-Based Digital Storytelling Project.From Cambridge University Press Language Teacher

Research.http://languageresearch.cambridge.org/ima ges/pdf/2015-

16_Widodo_CUP_TRP_final_report.pdf.

[8] Sulistiyo, U., Haryanto, E., Widodo, H. P., Elyas, T. (2019). The portrait of primary school English in Indonesia: policy recommendations. International Journal of Primary, Elementary and Early Years
Education, 3-13, DOI: $10.1080 / 03004279.2019 .1680721$

[9] Harmer, J. (2011). The practice of English Language Teaching. Edinburgh: Pearson Education Limited.

[10] Montessori, M. (1966). The secret of childhood (M. J. Costello, Trans.). New York, NY: Ballantine.

[11] Hakim, M.A.R \& Dian.A. (2015).“Developing English Text Book For Fourth Grade Studentsin Elementary School" dalam International Journal of Educational Studies, 12 (3), 29- 35

[12] Brown, H. Douglas. 2000. Principles of Language Learning and Teaching. New York: Longman.

[13] Lestariningsih, FransiscaEndang. (2018). "KebutuhanKompetensiPedagogiPengajarBahasaIng grisuntukTujuanKhususpada Abad-21." Seminar Nasional IKA UNY Retrieved from https://core.ac.uk/download/pdf/189575643.pdf

[14] Ayu, M. (2020). Evaluation Cultural Content on English Textbook Used by EFL Students in Indonesia. JET (Journal of English Teaching), 6(3), 183-192.

[15] Haque, S. (2017). A Content Analysis of English Textbook Related to Contextual Teaching and Learning (Doctoral dissertation, UniversitasMuhammadiyah Semarang).

[16] Zhang, C., \& Quinn, M. F. (2020). Preschool Children's Interest in Early Writing Activities and Perceptions of Writing Experience. the elementary school journal, 121(1), 52-74. 